\title{
Strategic alignment of product portfolio and supplier management
}

\author{
Jordan Verrollot*, Arto Tolonen, \\ Janne Harkonen and Harri Haapasalo
}

Industrial Engineering and Management,

University of Oulu,

Oulu, Finland

Email: jordan.verrollot@oulu.fi

Email: arto.tolonen@oulu.fi

Email: janne.harkonen@oulu.fi

Email: harri.haapasalo@oulu.fi

*Corresponding author

\begin{abstract}
Product portfolio management (PPM) and supplier management (SM) are integrally linked through products, buy items and related suppliers. However, the connection and alignment between these important activities are not particularly highlighted in the extant literature. Hence, the main objective of this study is to clarify the challenges in connecting PPM and SM to illustrate how they can be aligned. This study recognises and links the roles of PPM and SM to analyse and manage the technical product portfolio, buy items and suppliers according to aligned strategic targets. PPM impacts the performance of SM by regularly renewing the product portfolio, and therefore allowing SM to manage only the buy items and related suppliers that create the highest strategic fit, maximised value and balance for the company. This study recognises the need to align PPM and SM to enhance competitiveness and to focus on the strategic and profitable products and associated suppliers.
\end{abstract}

Keywords: product portfolio management; strategic alignment; supplier management; supply management.

Biographical notes: Jordan Verrollot received MSc in 2012 from the University of Technology of Troyes, France. He joined the Faculty of Technology at the University of Oulu, Finland in 2014. He is currently a doctoral student in Industrial Engineering and Management. His research interests include supply chain management, product management, product portfolio management and product development.

Dr Arto Tolonen received M.Sc. in Engineering (1992) and Dr (Tech) in Industrial Engineering and Management (2016) from the University of Oulu, Finland. Currently, he is a Senior Research Fellow in Industrial Engineering and Management at the University of Oulu. His current research interests are product management, product portfolio management, product data management and rapid product development. He has over 20 years of experience in development of business processes and operational management of Design for Excellence product design principles, delivery capability creation, supply chain management and product data management in global companies. 
Dr Janne Harkonen received Bachelor's degree (1st Class Honours) in Engineering Business Management from the University of Greenwich in the UK and both M.Sc. in Process Engineering and Dr (Tech) in Industrial Engineering and Management, from the University of Oulu, Finland. He has also studied in the University of North Carolina at Wilmington, USA. He has experience working in the IT and environmental technology industries. Currently, he is a Senior Research Fellow at the University of Oulu in Finland. Dr Harkonen has authored and co-authored over 40 journal articles, and also a number of other publications.

Harri Haapasalo is a Professor of Product Management at Industrial Engineering and Management, University of Oulu in Finland. He has two main areas of research: one in product management, product development and the second one in the area of complex systems management, lean construction and business models. He has been very active in obtaining research projects, and active in journal publications. His list of publications contains more than 250 international items. He has supervised more than 30 doctoral theses and been an external examiner for more than 30 doctoral dissertations.

\section{Introduction}

Nowadays, a wide product offering is seen to allow reaching many customer segments and a larger market share (Xia and Rajagopalan, 2009; Wan et al., 2012). In order to create more product variety, companies' focus tends to be mostly on the new product development (NPD) phase and consequently more products are added to the product portfolio than removed (Hoole, 2006; Droge et al., 2012). This generates a negative and unnecessary growth of companies' product portfolios in a profitability sense (Randall and Ulrich, 2001; Wan et al., 2012), leading to increased numbers of sales items, longer lead times, higher inventory levels and lower levels of customer service (Abbey et al., 2013). Product portfolio management (PPM) is a business concept that strives to strategically and cost-efficiently select and holistically manage the company's products over the lifecycle, including the removal of non-strategic and unprofitable products (Haines, 2009; Sadeghi and Zandieh, 2011; Jugend and da Silva, 2014).

On the supply chain side, it is clear that firms need to consider strategically the supplier management (SM) function because of the trend of companies concentrating on their core competencies, eventually leading to increasing levels of outsourcing (Leenders et al., 1994; Choi and Krause, 2006; McIvor et al., 2006; Shamsuzzoha et al., 2010). Companies across industries have become highly dependent on suppliers, which are seen to exert a major influence on a firm's success or failure (Monczka et al., 1993; Ellram and Carr, 1994). It is common that suppliers receive 50\% or more of a firm's total revenue and therefore an excellent SM is required to be successful in a highly competitive business environment (Burt, 1989; Trent, 2007). SM aims at identifying the company's total requirements, developing supply strategies that contribute to joint success, as well as selecting and managing the suppliers with similar goals in order to realise combined performance advantages (Goffin et al., 1997; Jack and Powers, 2015). 
Product portfolio management and SM are connected through the products' components, modules and assemblies that need to be purchased (Fixson, 2005; Jacobs and Swink, 2011). Suppliers providing those items must be identified, evaluated, selected and managed. Therefore, PPM affects the SM and vice versa (Jiao et al., 2007; Mansoornejad et al., 2010; Pashaei and Olhager, 2015). For instance, an explosion of the product portfolio may lead to an explosion of the supplier base, resulting in an explosion of the costs.

Academics and practitioners agree that the supply chains should be aligned with the company's products and product portfolio (Fisher, 1997; Lee, 2002; Langenberg et al., 2012). The scientific research proposes several ways to classify products and product portfolio with their related supply chain and purchase strategy (Kraljic, 1983; Fisher, 1997; Seifert and Langenberg, 2011; Langenberg et al., 2012). However, the connection and alignment between PPM and SM are not specifically highlighted in the scientific literature. There are few reasons for this. PPM is well covered in the literature regarding the NPD phase (Cooper, 2008; O'Reilly and Tushman, 2004; Weerd et al., 2006); however, the focus on the later phases of the product lifecycle has been neglected (Tolonen, 2015a). From the practical perspective, companies' visibility over the product portfolio has not been seen as consistent due to many different product views and missing reporting capabilities (Tolonen, 2015a). Nevertheless, the need for aligning PPM and business processes over the lifecycle phases has been recognised in the literature on business process management (Bai and Sarkis, 2013). SM is a key business process, a part of the supply chain business process (Cooper et al., 1997; Lambert and Cooper, 2000), and hence linking to PPM. The PPM as a concept allows the active alignment of product portfolio and business processes over lifecycle, including the effective SM (Tolonen et al., 2015b). This is an area, which is yet to be extensively covered by the literature.

The purpose of this research is to first analyse the potential interactions between PPM and SM and their alignment in terms of concepts, targets and product design rules. Second, this study reviews and analyses PPM, SM and their combination in an advanced company in order to clarify the related challenges and to provide an initial basis for strategically aligning PPM and SM. Third, the connection between PPM and SM as well as the proposed strategic alignment is presented in this paper.

\section{Literature}

\subsection{Product portfolio management}

Cooper et al. (1999) and Kester et al. (2011) state that PPM is an important activity for companies because, in conjunction with business strategy, PPM is responsible for determining not only projects for new products, but also revisions, updates and even decisions regarding the discontinuation of products that are currently produced and commercialised. Haines (2009) emphasises the concept by defining lifecycle PPM as an on-going, multi-dimensional, multi-phase, decision-making methodology that allows businesses to achieve strategic, market, financial and operational balance across every product in an organisation, across all lifecycle phases. PPM is a general business concept involving active decision-making in order to strategically and cost-efficiently determines 
the best set of products to create, sell, deliver and care (Georgiopoulos et al., 2002; Sadeghi and Zandieh, 2011).

An inefficiently managed portfolio can lead to many negative side effects such as missing strategic criteria in project selection resulting in unimportant and low value projects as well as deficient go/kill decisions for low value projects resulting in unnecessary extensions, modifications, enhancements, short-term projects and lack of focus (Cooper et al., 2001). Offering multiple similar products may lead to increased overall demand volatility, reduced forecasting accuracy, and impact revenue and cost of the products over the lifecycle (Ward et al., 2010), as well as to increase the complexity of product portfolios (Jacobs, 2013). Tolonen et al. (2014a) also identified challenges in the overall idea of PPM such as the lack of understanding of the role of PPM as strategic level analysis and decision-making process for the entire product portfolio over the lifecycle, the growing size of the product portfolio or the product cannibalisation.

Tolonen et al. (2015a) proposed a framework for PPM to cover the commercial and technical product portfolios structure over the product lifecycle and to respond to company's strategic targets. First, company's performance targets are seen important to be described in the form of a mission statement (Williams, 2008; King et al., 2010) comprising nine components (David, 1989). Second, Cooper et al. (1999) identified three basic performance objectives that PPM should achieve: the strategic fit, the balance and the value maximisation of the product portfolio. These PPM performance objectives are greatly accepted in several publications that focus on this topic (Mikkola, 2001; Miguel, 2008; Barczak et al., 2009; Oh et al., 2012). Strategic fit ensures that the company strategy is translated into a current or future set of products that will enable the business strategy (McNally et al., 2009; Jugend and da Silva, 2014). Balancing the product portfolio should be considered in terms of degree of innovation, long/short-term objectives, risk-reward, profits as well as the diversity of markets and technologies (Cooper et al., 1999; Oh et al., 2012). The maximisation of the product portfolio requires optimising the relation between resources used and projected returns (Kester et al., 2009; McNally et al., 2009). Third, the horizontal sub-portfolios should be created based on the four lifecycle phases: NPD, Maintain, Warranty and Archive (Saaksvuori and Immonen, 2008) in order to allow the on-going renewal and the flow of products across all lifecycle phases based on the related PPM targets and key performance indicators (KPIs) (Haines, 2009). Finally, because the business process management literature recognises the need for PPM and business processes alignment over lifecycle phases (Bai and Sarkis, 2012), the performance management dashboard connects the three key product portfolio performance focus areas (Cooper et al., 1999) with the business processes' strategic targets and KPIs. Implementing PPM governance model and ownership over all the product lifecycles and product structure levels are also seen necessary for effective PPM (Tolonen et al., 2014b).

\subsection{Supplier management}

Supply management and supplier management are used indifferently in the literature. On one hand, Supply management is seen as a strategic, proactive and cross-functional process for acquiring the organisation's current and future needs through effective management of suppliers (Trent, 2007; Spina et al., 2013). On the other hand, SM is described as identifying the company's total requirements, developing supply strategies that contribute to joint success, as well as selecting and managing a suitable set of 
innovative suppliers in order to realise combined performance advantages (Goffin et al., 1997; Jack and Powers, 2015). The term SM will be used later in this paper. Spekman et al. (1999) listed principles for effective sourcing and SM including integrating suppliers into the supply chain, focusing on total costs, or rationalising the supply base. SM is seen as a key area since it can have a significant impact on company's costs, quality, innovation and competitive position (Lemke et al., 2000; Zhao et al., 2014).

The SM concept is seen different from the traditional purchasing approach (Kraljic, 1983; Goffin et al., 1997; Cho et al., 1998). Traditional purchasing, also known as the arm's length model, focuses on unit price (Lamming, 1993), quality conformance and speed of delivery (Dickson, 1966; Goffin et al., 1997). The related buyer-supplier relationship is short term (Kraljic, 1983), multi-sourcing (Harland, 1996; Krause, 1999) and adversarial (Monczka and Trent, 1991; Scott and Westbrook, 1991). On the other hand, SM relates to the need to comprehensively and concurrently manage seven major criteria related to suppliers (Phusavat et al., 2007). SM focuses on total cost/impact on profitability (Kraljic, 1983; Larson, 1994; Morssinkhof et al., 2011), quality record/use of TQM (Larson, 1994; Foster et al., 2011), delivery/cycle times/JIT (Lee and Wellan, 1993; Prajogo and Olhager, 2012; Singh and Ahuja, 2012), financial stability (Chan et al., 2008), technology capabilities (Monczka et al., 1993), service (Ho et al., 2010) or risks (Blome and Schoenherr, 2011; Hoffmann et al., 2013). The related buyer-supplier relationship is long-term (Kraljic, 1983; Hartley and Choi, 1996), single or dual sourcing (Swift, 1995; Harland, 1996) and based on dependence and trust (Hartley and Choi, 1996).

Purchasing is no longer thought to be purely tactical, but it is now recognised as a strategic function (Kraljic, 1983; Ellram and Carr, 1994; Goffin et al., 1997). External suppliers are seen to exert a major influence on a company's success or failure (Monczka et al., 1993; Ellram and Carr, 1994). Traditional purchasing approach does not bring competitive advantages anymore and is no longer an economically sensible approach in most industries because of the high cost of managing a large supplier base (Gadde and Snehota, 2000) or reduced economies of scale due to dividing purchases across multiple suppliers (Dyer et al., 1998).

The rationalisation of the supplier base is seen as an important component of effective and strategic sourcing (Spekman et al., 1999; Gordon, 2008). The main reason identified for supplier base rationalisation and reduction is the need to manage suppliers more effectively and to have more time and resources available to develop a closer relationship with each supplier (Goffin et al., 1997; Cadden and Downes, 2013; Talluri et al., 2013). Managing an optimal size of supplier base should lead to a competitive advantage for the buyer, through reduced costs, higher quality and innovation resulting from the support of suppliers in the product or process development (Leenders et al., 1994; Chen and Paulraj, 2004; Talluri et al., 2013).

Supplier management can also be examined through the supply network complexity. A supply network refers to a network of firms engaged in manufacturing and assembly of parts to create a finished product. A product with a large bill of materials tends to show a large membership in the network (Lamming et al., 2000; Choi and Hong, 2002). The complexity in supply network refers to the number of tiers (vertical complexity), the number of suppliers in each tier (horizontal complexity) and the average distance between two firms engaged in buying and supplying (spatial complexity). In addition, intangible measures such as the level of coupling between firms are part of the complexity (Daft, 1989; Choi and Hong, 2002). 


\subsection{Combining product portfolio management and supplier management}

\subsubsection{Critical issues in combining PPM and SM}

The type of item to be purchased has a major influence on the aspects that are considered when selecting a supplier (Dickson, 1966; Kraljic, 1983; Goffin et al., 1997; Cho et al., 1998; Gadde and Snehota, 2000; Lamming et al., 2000). Thus, critical factors and methods to combine products/product portfolios with supply chains and supply strategies are explained in the scientific literature. Supply chains must be tightly aligned with a company's business context and their alignment with the entire product portfolio holds the potential for cost savings (Fisher, 1997; Langenberg et al., 2012). The critical issues can be divided into the product type (Fisher, 1997; Kraljic, 1983; Dyer et al., 1998; Hsuan, 1999; Petroni and Panciroli, 2002) and the product portfolio type (Seifert and Langenberg, 2011; Langenberg et al., 2012).

First, concerning issues related to the product type, Kraljic (1983) proposes a purchasing segmentation that is in line with the impact on profit and the supply risk of the purchased materials and components. As a result, products are divided into four categories: routine, leverage, bottleneck and strategic. Fisher (1997) provides a framework in which products are divided into functional or innovative according to their demand predictability, lifecycle length or variety. Another way to separate suppliers is the strategic supplier segmentation, which results in the division into two categories: strategic partners and durable arm's length suppliers according to the value and degree of differentiation of the supplied input (Dyer et al., 1998; Hsuan, 1999; Petroni and Panciroli, 2002). The durable arm's length model fits best the low value, non-strategic inputs that are not related to the buying firm's core competence or those that do not play significant role in differentiating the buying firm's products while strategic partners provide high-value inputs to the buying firm's core competencies and play an important role in differentiation of the buyer's final products (Dyer et al., 1998; Hsuan, 1999). These two relative postures are characterised by different degrees of collaboration in product development, R\&D integration, inter-firm knowledge, risk sharing, mutual trust, level of communication and resource allocation (Petroni and Panciroli, 2002).

Second, concerning issues related to the product portfolio type, Seifert and Langenberg (2011) describe four different product portfolio dynamics (stable, commoditising, discontinuous or dynamic) according to the rate of new product introductions and commoditisation. Langenberg et al. (2012) propose a product portfolio classification according to the degree of product portfolio heterogeneity and innovativeness. Heterogeneity indicates how similar the products in the portfolio are compared to one another while innovativeness indicates the degree to which the average product in the portfolio is functional or innovative.

\subsubsection{Means and methods for combining PPM and SM}

Kraljic (1983) describes four different purchasing strategies according to the level of supply risk and impact on profit. Routine products require system contracting and ecommerce solutions, leverage products necessitate competitive bidding, bottleneck products need secure supply and search for alternatives and strategic products require partnerships. Fisher (1997) recommends that functional products require efficient supply chain and innovative products necessitate responsive supply chain. Dyer et al. (1998), 
Hsuan (1999), Petroni and Panciroli (2002) describe two strategies according to the supplier category. Durable arm's length suppliers require, for example, low face-to-face communication and frequent price benchmarking while strategic partners necessitate managerial assistance, exchange personnel and relation-specific investments. Seifert and Langenberg (2011) propose different levels of supply chain adaptation - defined as modifying supply networks over time to meet structural shifts in markets - according to four different product portfolio dynamics. For example, no supply chain adaptation is required for stable product portfolios, whereas a high adaptation strategy is required for commoditising product portfolios in order to retain company's competitiveness. Langenberg et al. (2012) state that an innovative product portfolio requires a set of market responsive supply chains, whereas a functional product portfolio a set of physically efficient supply chains. The higher the heterogeneity of the product portfolio, the higher is the necessity to use a supply chain portfolio instead of a single chain.

Product variety strategy is a key driver in the connection between PPM and SM. As product variety increases, the variety of at least some purchased product components may increase (Fisher et al., 1999) and suppliers may experience diseconomies due to component variety, with potential negative impact on component prices, delivery times and component inventory levels (McCutcheon et al., 1994; Krishnan and Gupta, 2001). Accordingly, a trade-off exists between product variety and operational performance of internal operations as well as component sourcing performance (Salvador et al., 2002). Some firms have lately sought to optimise the number of products they offer, trading off the benefits of a larger product portfolio for lower supply-chain performance (Thonemann and Bradley, 2002). However, it is widely seen appropriate to increase product variety in order to better respond to heterogeneous customer needs (Xia and Rajagopalan, 2009; Wan et al., 2012). Product variety is related to supply chain structure through its effect on production costs and market mediation costs (Randall and Ulrich, 2001). Variety is production-dominant if the increase in production costs associated with increased variety surpasses the increase in market mediation costs. Conversely, variety is mediation-dominant if the increase in mediation costs associated with increased variety outweighs the increase in production costs (Yadav et al., 2011). Matching of production dominant variety with the scale efficient production and matching of the market mediation-dominant variety with local plants lead to firm's better performance (Randall and Ulrich, 2001; Yadav et al., 2011).

It is recognised that the trade-off between product variety and operational performance can be mitigated by product modularity (Huang and Kusiak, 1998; Gershenson et al., 2003). Modularisation is an approach to organise complex designs and process operations more efficiently by decomposing complex systems into simpler and independent portions. Therefore, modules allow the designer to play with combinations of groups of components to develop and customise a larger quantity of products in a product family (He and Kusiak, 1996; Gershenson et al., 2003; Jose and Tollenaere, 2005). Inside a modular architecture, commonality potential and differentiation should be carefully balanced to simultaneously maximise the use of common components and allow maximum distinctiveness between products. The objective is to develop and produce very distinctive products, which share as many parts as possible (Robertson and Ulrich, 1998; Jose and Tollenaere, 2005; Karlsson and Sköld, 2007). Modularity enables using fewer unique parts and using same modules allow companies to achieve economies of scale when parts are procured and produced in greater quantities (Erixon, 1996; Gershenson et al., 2003). Cutting the number of parts and processes benefits both product 
development (Huang and Kusiak, 1998) and supply chain management (Ulrich et al., 1993; Gershenson et al., 2003).

Product data management (PDM) and cross-functional collaboration also facilitate the link between PPM and SM. Efficient PDM allows similar or standard parts, processes and other design information to be grouped by common attributes and retrieved for use in products leading to greater product standardisation, reduced re-design, savings in purchasing and fabrication, and reduced inventories (Philpotts, 1996). Co-operation and collaboration between functional departments in organisations are seen important, based on the premise that interdepartmental collaboration is linked to improving business performance (Ellinger, 2000). Collaboration is seen to improve logistical effectiveness, firm's overall performance and financial performance (Gimenez and Ventura, 2005; Sanders and Premus, 2005; Germain and Iyer, 2006).

\subsubsection{Literature synthesis}

Table 1 presents the synthesis of the main critical issues in linking products/product portfolios with SM and their related means and methods.

Table 1 Main critical issues in linking product/product portfolio with supplier management

\begin{tabular}{|c|c|c|}
\hline Critical issues & Explanation & Means/methods \\
\hline 1 Supply risk & $\begin{array}{l}\text { High/low supply risk of items } \\
\text { supplied (in terms of } \\
\text { availability, number of } \\
\text { suppliers, substitution } \\
\text { possibilities, etc.) }\end{array}$ & \multirow{2}{*}{$\begin{array}{l}\text { Adapted supply strategies according } \\
\text { to the level of supply risk and impact } \\
\text { on profit. Four distinctive purchasing } \\
\text { approaches: system contracting and e- } \\
\text { commerce solutions, competitive } \\
\text { bidding, secure supply, partnerships } \\
\text { (Kraljic, 1983). PDM leads to greater } \\
\text { product standardisation and savings in } \\
\text { purchasing (Philpotts, 1996) }\end{array}$} \\
\hline $\begin{array}{l}2 \text { Impact on } \\
\text { profit/profitability } \\
\text { profile }\end{array}$ & $\begin{array}{l}\text { High/low impact on profit of } \\
\text { items supplied (volume } \\
\text { purchased, percentage of total } \\
\text { purchase cost, etc.) }\end{array}$ & \\
\hline $\begin{array}{l}3 \text { Predictability of } \\
\text { the demand }\end{array}$ & $\begin{array}{l}\text { Predictable/unpredictable } \\
\text { demand }\end{array}$ & \multirow{2}{*}{$\begin{array}{l}\text { Products classified as innovative or } \\
\text { functional according to the } \\
\text { predictability of the demand, the } \\
\text { product lifecycle length or product } \\
\text { variety. Two distinctive types of } \\
\text { supply chains: physically efficient } \\
\text { and market-responsive (Fisher, 1997) }\end{array}$} \\
\hline 4 Product lifecycle & $\begin{array}{l}\text { Short/long product lifecycle. } \\
\text { Product lifecycle consideration } \\
\text { in both PPM and SM }\end{array}$ & \\
\hline \multirow[t]{2}{*}{$\begin{array}{l}5 \text { Product variety, } \\
\text { product portfolio } \\
\text { proliferation }\end{array}$} & \multirow[t]{2}{*}{$\begin{array}{l}\text { High/low product variety. } \\
\text { Proliferation of product } \\
\text { portfolio and cannibalisation }\end{array}$} & $\begin{array}{l}\text { Categorisation of the product variety } \\
\text { and matching product variety with } \\
\text { supply chains (Randall and Ulrich, } \\
\text { 2001; Yadav et al., 2011) }\end{array}$ \\
\hline & & $\begin{array}{l}\text { High product variety mitigated by } \\
\text { product modularity (Huang and } \\
\text { Kusiak, 1998; Gershenson et al., } \\
\text { 2003). Modularity, by allowing the } \\
\text { use of fewer unique parts, leads } \\
\text { companies to achieve economies of } \\
\text { scale when parts are produced in } \\
\text { greater quantities (Erixon, 1996; } \\
\text { Gershenson et al., 2003) }\end{array}$ \\
\hline
\end{tabular}


Table 1 Main critical issues in linking product/product portfolio with supplier management (continued)

\begin{tabular}{|c|c|c|}
\hline Critical issues & Explanation & Means/methods \\
\hline Value & $\begin{array}{l}\text { Low/high-value, strategic/non- } \\
\text { strategic inputs. Focus on high- } \\
\text { value products and related } \\
\text { items to supply. }\end{array}$ & $\begin{array}{l}\text { Strategic supplier segmentation } \\
\text { between durable arm's length } \\
\text { model and strategic partners (Dyer } \\
\text { et al. 1998; Hsuan, 1999) }\end{array}$ \\
\hline \multirow[t]{2}{*}{ Differentiation } & $\begin{array}{l}\text { Important/minor role of the } \\
\text { supplier in differentiation of the } \\
\text { buyer's final products }\end{array}$ & $\begin{array}{l}\text { Different degrees of R\&D integration, } \\
\text { risk sharing, mutual trust, resource } \\
\text { allocation, etc. (Petroni and Panciroli, } \\
\text { 2002) }\end{array}$ \\
\hline & & $\begin{array}{l}\text { Rationalisation of the supplier base } \\
\text { leading to a competitive advantage for } \\
\text { the buyer (Leenders et al. 1994; Chen } \\
\text { and Paulraj, 2004; Talluri et al., 2013) }\end{array}$ \\
\hline $\begin{array}{l}\text { Product portfolio } \\
\text { heterogeneity and } \\
\text { innovativeness }\end{array}$ & $\begin{array}{l}\text { Balance between innovative } \\
\text { and functional products }\end{array}$ & $\begin{array}{l}\text { Innovative product portfolio } \\
\text { requires a set of market responsive } \\
\text { supply chains, whereas a functional } \\
\text { product portfolio a set of physically } \\
\text { efficient supply chains (Langenberg } \\
\text { et al., 2012) }\end{array}$ \\
\hline $\begin{array}{l}\text { Portfolio } \\
\text { dynamics }\end{array}$ & $\begin{array}{l}\text { Rate of new product } \\
\text { introduction and product } \\
\text { commoditisation }\end{array}$ & $\begin{array}{l}\text { Different levels of supply chain } \\
\text { adaptation according to different } \\
\text { product portfolio dynamics (Seifert } \\
\text { and Langenberg, 2011) }\end{array}$ \\
\hline
\end{tabular}

\section{Research process}

The nature of this research is qualitative. First, the existing literature was reviewed to obtain an understanding of the research that has been carried out on PPM, SM and the connection of these two functions. The literature review provided a basis for the empirical analysis, which was carried out as an interview study in the analysed company. The research process is presented in Figure 1.

Figure 1 Research process

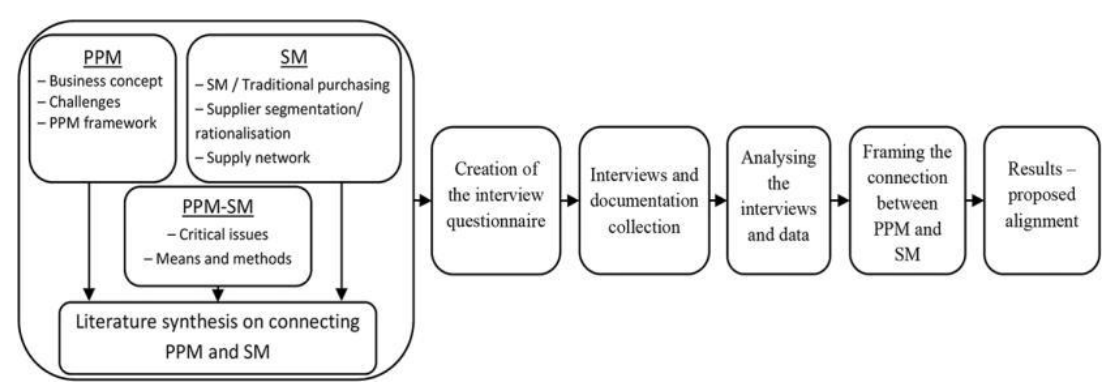

The particular focus on the strategic alignment of PPM and SM necessitates investigating the phenomena first with as rich data as possible while confined to intimately analysing a company with advanced enough practices. The research setting illustrates one example 
and provides insights into the rationale of coexistence of these two important concepts (Arbnor and Bjerke, 2008). This type of studies is deemed suitable for exploratory purposes (Yin, 2003), in this instance exploring the alignment of PPM and SM. Such studies can be used to provide exemplary examples of the studied phenomena (Sigglekow, 2007) while a setting with analysing a single company enables one to gain some understanding of the causal relations of the topic of interest (Eisenhardt, 1989).

The qualitative data were collected from a single case company during interview sessions. Analysing a single company score low on generalisability of findings, yet, on the other hand, the richness of data support inductive reasoning. It is particularly this intimate linkage with the empirical reality that allows using this type of method so that the reality can later be tested by other means (Eisenhardt, 1989). Separate interview sessions focused on PPM and on SM and the combination between PPM and SM. The interviews' goals were to clarify the current practices and challenges related to the studied topics. The perspective taken in this study is purely a systemic view of PPM and SM as a system managed by company managers. Hence, external views in the form of data from suppliers are not gathered. A major global company was selected based on suitability, current interests on the topic and the opportunity to have an access to interview experienced experts on the studied subject. In all, 13 interviewed industry experts were carefully selected based on their professional background and expertise. Selected participants hold responsible senior positions related to product management, product development, sourcing and supply chain management. The experience and the current interests ensured high motivation among the participants and up-to-date knowledge with respect to the discussed topics. The company characteristic and the interview settings are presented in Table 2.

Table 2 Company characteristic and interviews

\begin{tabular}{|c|c|}
\hline $\begin{array}{l}\text { Company } \\
\text { characteristics }\end{array}$ & $\begin{array}{l}\text { The case company is a world leader in its business, operates in business- } \\
\text { to-business markets providing equipment and services to a variety of } \\
\text { customers, including manufacturing and process industries, shipyards, } \\
\text { ports and terminals. The company has more than } 10,000 \text { employees, } \\
\text { operations in a number of countries and revenue of several billion. The } \\
\text { company has grown through acquisitions }\end{array}$ \\
\hline $\begin{array}{l}\text { Product Portfolio } \\
\text { characteristics }\end{array}$ & $\begin{array}{l}\text { Large product portfolio of solutions, HW and services. Global, regional } \\
\text { and local business customers. Mature and new innovative HW and } \\
\text { services in global mature business. Equipment and service business } \\
\text { areas. Equipment has six different business units. Long product lifecycle. } \\
\text { Recently grown product portfolio. Hundred thousands of different } \\
\text { products. 'Engineer to order' or 'make-to-stock' products }\end{array}$ \\
\hline \multirow[t]{3}{*}{$\begin{array}{l}\text { Supplier } \\
\text { characteristics }\end{array}$} & $\begin{array}{l}\text { High dependence on suppliers (more than } 50 \% \text { of revenue is spent with } \\
\text { the suppliers). }\end{array}$ \\
\hline & $\begin{array}{l}10000 \text { suppliers. Target of at least dual-sourced components. Majority of } \\
\text { suppliers are followed by defined supplier managers. Regional supplier } \\
\text { base due to intercontinental operations, long lead-times, high logistics }\end{array}$ \\
\hline & cost and product not always transportable overseas \\
\hline $\begin{array}{l}\text { Interviewees' } \\
\text { responsibilities }\end{array}$ & $\begin{array}{l}\text { Product ownership, Product management, IT PLM, Global production } \\
\text { engineering, Supply chain management development, Global sourcing, } \\
\text { Supply chain management, Product development engineering, Services } \\
\text { business }\end{array}$ \\
\hline
\end{tabular}


Two distinct interview questionnaires were utilised. The first questionnaire covered the PPM and the second one dealt with SM and its combination with PPM. The interviews covered relevant themes, including current product portfolio, PPM processes and tools, relevant governance models, relevant targets and KPIs, connections to other business processes, PPM-related main challenges, SM, impacts of PPM on SM, impacts of SM on PPM, alignment of SM and PPM. Interviews were conducted in a qualitative manner using mostly open-ended questions, allowing the interviewees to clarify and explain the cases and the topics (Saunders et al., 2007). The interviews were conducted by a single researcher, recorded and transcribed to enable thorough analyses. The interviews enabled analysing:

1 how the analysed company deals with PPM, SM and their combination

2 their practical challenges

3 possible good practices.

In addition, suitable relevant company documentation was analysed to support the interview findings. Data were analysed by creating and utilising an analysis template to flag relevant aspects on PPM and SM and their combination. Any remarks were kept separate from the evidence. To avoid researcher bias, colleagues and co-authors confirmed and took part in the analysis. The collected data enabled describing the company's challenges in the research topics. The challenges are presented following the process management methodology and structure (Slack et al., 2012; Bai and Sarkis, 2013) and divided into four sub-groups: challenges in general, related to processes and tools, related to target setting and KPIs and related to ownership and governance models. The findings were compared with literature to reveal any similarities and conflicts.

\section{Results and analysis}

\subsection{Challenges in PPM, SM and combining them}

The company's challenges in PPM, SM and PPM-SM relation are hereafter presented and divided into three distinct tables. Table 3 presents the challenges of PPM, Table 4 SM challenges and Table 5 those combining PPM and SM.

Table 3 Practical challenges of PPM in the company

\begin{tabular}{ll}
\hline General & The idea and the role of PPM as higher-level analysis and decision- \\
& making process for the entire product portfolio including new and \\
& existing products are not thoroughly understood \\
& The size and proliferation of the product portfolio have resulted in \\
& product cannibalisation \\
& Lack of product portfolio level business case thinking and unplanned \\
& durations of product lifecycles \\
& Targets mostly focused on value maximisation of individual products \\
& rather than product portfolio \\
Targets \& KPIs & Lack of target settings/KPIs over the product lifecycles \\
\hline
\end{tabular}


Table 3 Practical challenges of PPM in the company (continued)

\begin{tabular}{ll}
\hline Processes \& tools & $\begin{array}{l}\text { Process management concepts and descriptions have not been } \\
\text { implemented for the entire product portfolio management } \\
\text { Lack of strategic and tactical product portfolio management tools } \\
\text { Governance models }\end{array}$ \\
\hline Table 4 & $\begin{array}{l}\text { Lack of clarity in product portfolio ownership over the lifecycles } \\
\text { Absence of product portfolio management function }\end{array}$ \\
\hline General & Difficulty to use the preferred supplier concept as different lists of \\
& $\begin{array}{l}\text { preferred suppliers coexist } \\
\text { Too many suppliers to manage due to the necessity of significant } \\
\text { regional supplier base } \\
\text { Challenges in supplier selection and their location (due to very different } \\
\text { lead times, different currencies, different norms and risks) }\end{array}$ \\
Targets \& KPIs & $\begin{array}{l}\text { How to measure the level of innovation provided by the suppliers: how } \\
\text { to measure the difference between what is expected from the suppliers } \\
\text { and what is actually received } \\
\text { Managing the right number of suppliers for single components } \\
\text { Challenges in finding alternative sources for some components } \\
\text { Monitoring the demand-supply balance and better sharing this } \\
\text { information with the suppliers } \\
\text { Challenges in the implementation of a supplier evaluation tool to } \\
\text { improve supplier performance } \\
\text { Challenges in the supplier selection decisions, unclear governance in } \\
\text { decision-making }\end{array}$ \\
\hline
\end{tabular}

Table 5 Practical challenges of combining PPM and SM in the company

\begin{tabular}{ll}
\hline General & $\begin{array}{l}\text { Challenges in associating the preferred supplier program with strong } \\
\text { purchasing power and alternative sourcing possibilities } \\
\text { Conflicts between the PPM and SM on supplier selection decisions }\end{array}$ \\
Targets \& KPIs & $\begin{array}{l}\text { Conflicting targets and incentives by the senior management to PPM and } \\
\text { SM }\end{array}$ \\
Processes \& tools & $\begin{array}{l}\text { Information sharing on customer's expectations between the front sales, } \\
\text { PPM and SM }\end{array}$ \\
Governance models & $\begin{array}{l}\text { Insufficient connection between SM, product development and PPM and } \\
\text { subsequently between the component owners and supplier managers }\end{array}$ \\
& $\begin{array}{l}\text { Challenges in connecting product portfolio ownership with the supplier } \\
\text { ownership over the product lifecycles }\end{array}$ \\
\hline
\end{tabular}

Product portfolio management concept is neither thoroughly understood nor implemented in the company and its difference with the product management is not clearly recognised. SM concept is well implemented in the company. The challenges are mostly related to managing an overly large supply base, the supplier selection decisions and the collaboration with the suppliers. Due to a limited PPM implementation, combining PPM and SM is seen challenging in terms of the general concept, targets and governance 
models. The challenges are essentially about the collaboration between PPM and SM including the supplier selection, information sharing as well as the target settings and incentives given by the senior management.

\subsubsection{Motivation for aligning PPM and SM}

The company strives to align PPM and SM as it is seen beneficial due to many buy items in their technical product portfolio. The company emphasises the role of product managers as analysts and experts of the product portfolio in terms of strategy, competition, price, cost and profitability or risk position. The current product portfolio encompassed hundreds of thousands of different products and its structure is highly complex, consisting of numerous buy items, in every layer of the technical product portfolio, which needs to be managed across the product lifecycle phases. Consequently, developing PPM is seen crucial to make better product decisions, to avoid product portfolio explosion commercially and technically, to focus on strategic products as well as to minimise the number of technical assemblies such as buy items, manufactured items and components across the portfolio. PPM aims to improve the strategic fit and profitability. The profitability of the product portfolio can be improved by increasing the sales price and decreasing the cost of products.

The supplier managers are responsible for supplier business relationship, risk, quality and cost performance affecting directly to the cost of the products and product portfolio profitability. The majority of the suppliers are managed according to the SM targets and KPIs by defined supplier managers in order to evaluate their performance. Despite difficulties concerning the preferred supplier's program, it is still being improved and long-term and strategic relationships with suppliers are seen essential. Additionally, the large supplier base is being reduced as it is not possible to properly qualify, contract and manage this many suppliers, and it generates complexity, lower quality as well as higher cost and risk.

The large product portfolio is causing complexity to the SM because it requests a high number of suppliers to supply the extensive amount of buy items. Reducing the total number of different technical buy items as assemblies and components, and improving modularity by combining similar components in different products is thought to promote the purchasing power and lower cost of the product portfolio. A good cooperation between PPM and SM creates positive results such as avoiding the use of out-dated buy items, improving the profitability of the product portfolio as well as limiting the product portfolio and supplier base proliferation. The collaboration and alignment between PPM and SM are seen necessary to deliver performant products that are meeting the customers' expectations with right quality, cost and time. In addition, the strategic alignment is supported by the top management's commitment to those tasks.

\subsection{Proposal for PPM and SM alignment}

The SM - developing supply strategies; identifying, evaluating and selecting suppliers; managing, developing and balancing the supplier and material base to realise performance advantages - can be recognised as a portfolio management of suppliers. Therefore, the role of the SM should be to manage the suppliers creating the highest strategic fit and minimised cost in a balanced manner. PPM affects the performance of business processes by frequently renewing the product portfolio (PP) and thus enabling 
the business processes to create, sell, deliver and care only the group of products that are creating the highest strategic fit, minimised cost, maximised value and the balance for the company and its stakeholders. Consequently, PPM influences the performance of the SM by frequently renewing the product portfolio and thus enabling the SM to manage only the suppliers who supply the buy items related to the group of products that create the highest strategic fit, maximised value and balance for the company. Suppliers must be selected, managed and developed for all the buy items and consequently, they are subjected to SM. In order to better recognise PPM as a full business process that determines the products to be created, sold, delivered and cared, the link between PPM and SM needs to be analysed. Figure 2 proposes how to illustrate the relationship between PPM and SM through product portfolio structure.

Figure 2 Proposed PPM-SM connection through product portfolio structure

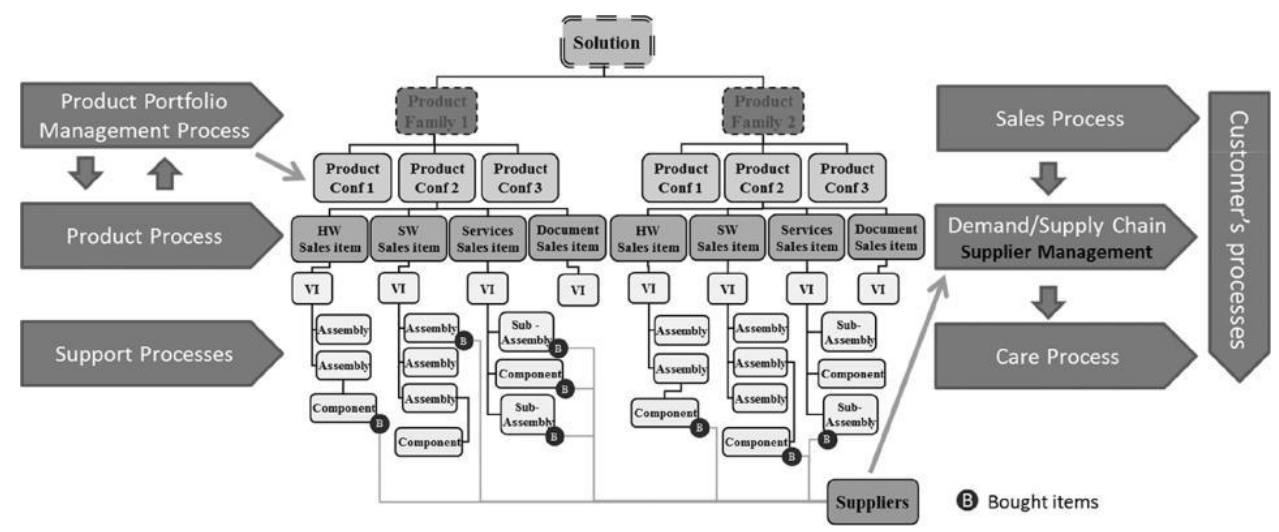

To understand more deeply the relationship between PPM and SM, the product portfolio structure is utilised. PPM process manages and controls vertically the commercial and technical product portfolios from the highest commercial solutions to the lowest level of technical components. Each technical buy item from version items (VI) to individual components needs to be supplied externally and consequently require suppliers. Those suppliers are subjected to SM.

The connection between PPM and SM can also be seen through the relation between the product portfolio and the supplier structure (Figure 3). The vertical and horizontal complexity of the supplier network is directly affected by the number of different buy items across the product portfolio. The strategic supplier segmentation, the targets concerning the number of different suppliers for each buy item and the ability to improve the modularity and commonality across the PP affect both the supplier network and product portfolio complexity. As an interviewee mentioned, combining similar components in different products can reduce our supplier base and leverage our purchasing power. PPM directly affects SM and vice versa. Hence, PPM and SM seem to have an obvious connection. 
Figure 3 Product portfolio and supplier network structure impact on each other

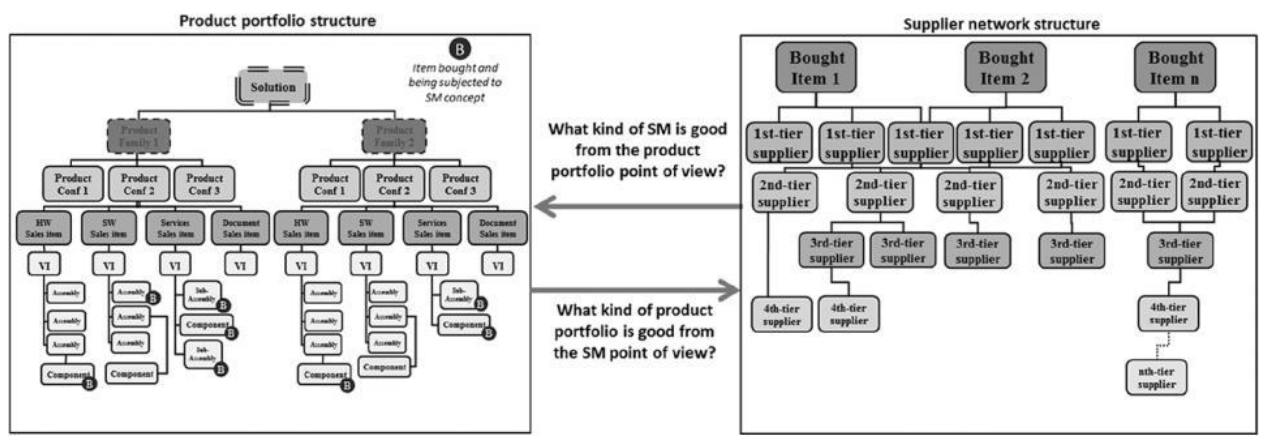

A more comprehensive link between PPM and SM is needed to understand what kind of SM is good from the PPM viewpoint and which kind of product portfolio is good from the SM viewpoint. An analysis template - created for the purpose of this study (Appendix) by utilising the literature and the empirical data from the company - parallels PPM, SM, their effects on each other and their alignment in terms of strategic targets, business process targets as well as product design guidelines, targets and metrics. From this analysis, we can deduce the fundamental alignment between PPM and SM (Table 6).

Table 6 The proposed strategic alignment between PPM and SM

\begin{tabular}{|c|c|}
\hline Product portfolio management & Supplier management \\
\hline Strategic/non-strategic products & Strategic/non-strategic suppliers \\
\hline $\begin{array}{l}\text { Profitable/break-even/unprofitable products } \\
\text { and items }\end{array}$ & Cost-effective/non-cost effective suppliers \\
\hline Low/High-risk products & Low/high-risk suppliers \\
\hline Short/long-term products & Short/long-term suppliers \\
\hline $\begin{array}{l}\text { Resources allocated to strategic/non-strategic } \\
\text { products }\end{array}$ & $\begin{array}{l}\text { Resources allocated to strategic/non-strategic } \\
\text { suppliers }\end{array}$ \\
\hline $\begin{array}{c}\text { Resources allocated to profitable/break- } \\
\text { even/Unprofitable products }\end{array}$ & $\begin{array}{l}\text { Resources allocated to cost-effective/non-cost- } \\
\text { effective suppliers }\end{array}$ \\
\hline Product portfolio size & Supplier base size \\
\hline $\begin{array}{l}\text { List of recommended products } \\
\text { and buy items }\end{array}$ & $\begin{array}{l}\text { List of recommended suppliers } \\
\text { and buy items }\end{array}$ \\
\hline
\end{tabular}

Product portfolio management aims at a balanced product portfolio that fits the company's strategy, and with a maximised value. SM aims at selecting, managing and developing the suppliers to match the company's strategy in terms of cost, quality, flexibility, time, innovation and sustainability. Respectively, recommended products, buy items and suppliers result from coordinated and aligned PPM and SM. Strategic fit, balance and value maximisation of both the PPM and SM should be considered to align these two functions. As an interviewee stated, Active collaboration between product management, product portfolio management and supplier management is necessary to reach this objective. The potential facilitators for improving the connection between the PPM and SM include strategic supplier segmentation, matching product variety with 
supply chains, developing product modularity, efficient PDM as well as improving the knowledge on PPM concept, targets and ownership of the involved stakeholders. It is also worth noting - as an interviewee mentioned - the alignment between PPM and SM is facilitated when the senior management aligns the targets and give similar incentives.

\subsubsection{Preconditions for aligning PPM and SM}

We propose five preconditions to facilitate the alignment between PPM and SM. They can be summarised as:

1 Creation of basic understanding of the PPM concept

The understanding of PPM concept can be triggered by explaining the negative impacts of the lack of PPM. Thereafter, a basic training on the idea, concept and practices of PPM can be established as well as the related benefits, goals and targets.

2 Description of SM concept

Company's SM concept can be defined and described. The current practices, benefits, goals and target of SM should then be emphasised.

3 Defining and implementing PPM strategic targets and KPIs

PPM strategic targets and KPIs can be created based on company strategy. Those targets can be divided into strategic fit, value maximisation, balance and size of the product portfolio. The PPM ownership and governance model should also be established.

4 Describing and updating SM strategic targets and KPIs

The current SM strategic targets and KPIs can be described and if needed updated based on the company strategy. The targets can be divided as strategic fit, minimised cost, value maximisation, balance and size of the supplier base. The SM ownership and governance model should also be emphasised.

5 Alignment of PPM and SM

The roles of PPM and SM affecting to each other should be understood and materialised. Therefore, PPM and SM can be paralleled in terms of concept, targets, metrics and ownership. The PPM and SM targets can be aligned in terms of strategic fit, value maximisation, balance and size. The product portfolio owners and supplier managers should collaborate and be closely connected. The fundamental alignment between these two functions can be deduced and seen as aligning the list of recommended products, buy items and suppliers.

\section{Discussion}

Supplier management topics are broadly covered across the scientific literature due to the continuous importance of strategic outsourcing and the increased dependence on suppliers. Concerning PPM, the NPD phase is relatively well-researched (Cooper et al., 1999; Kester et al., 2011; Hoole, 2006; Droge et al., 2012); however, the research is more limited concerning the remainder of the lifecycle phases. Only a few authors recognise the other phases in conjunction with PPM (Haines, 2009; Jugend and da Silva, 2014; Tolonen et al., 2014b). This study supports the previous studies with more narrow PPM focus but particularly provides a contribution to the wider consideration of PPM through 
the product lifecycle and product structure levels. Similarly, research specifically on the relationship and the implications of PPM on SM and supplier base is lacking. This research provides a new contribution to literature by recognising the need for aligning PPM and SM. This study particularly supports SM positioning under the business process of supply chain process (Cooper et al., 1997; Lambert and Cooper, 2000), further showing how the link between PPM and SM resides in the business processes, hence supporting the findings by Bai and Sarkis (2013). This study is also linked with the necessity of aligning PPM and business processes over the lifecycle phases (Bai and Sarkis, 2013). The connection and impact of the aligned PPM and SM on buy items through the technical product portfolio are identified in this study. This work supports previous connected studies, for example, Lamming et al. (2000) who assert that supply networks of complex products are more complex to manage as a consequence of the large number of components and hence actors involved, and study by Choi and Hong (2002) stating that a product with a large bill of materials and buy items tends to show a large membership in the supplier network.

Academics and practitioners agree that the supply chains should be aligned with the company's products and product portfolio (Fisher, 1997; Lee, 2002; Langenberg et al., 2012). This article contributes to this topic by identifying as well as analysing the combination and the link between PPM and SM. A framework for strategically aligning PPM and SM is then introduced. The three PPM basic performance objectives - strategic fit, value maximisation and portfolio balance - are utilised which supports the previous research on their importance in the management of a product portfolio (Cooper et al., 1999; Mikkola, 2001; Miguel, 2008; Barczak et al., 2009; Oh et al., 2012). In this study, for analysis purposes, the concept of SM is considered as portfolio management of suppliers and buy items. This assertion can be justified by the description and the focus of SM highlighted in the literature (Goffin et al., 1997; Jack and Powers, 2015; Kraljic, 1983; Morssinkhof et al., 2011; Chan et al., 2008; Hoffmann et al., 2013). Consequently, the same three basic performance objectives as for PPM are used in the introduced framework in order to align PPM and SM strategically. As a result, the fundamental alignment between PPM and SM is proposed.

The managerial implications of this research include showing the benefit of the aligned PPM and SM strategies. This study facilitates the representation of the connection between PPM and SM by utilising the product structure description as the base for commercial and technical product portfolios. The simplification of the technical product portfolio as a number of different buy items can streamline the supplier network and result in more focused supplier relationships. As the same logic, by rationalising the supplier network, the product portfolio can be simplified. An optimised size of product portfolio, buy items and supplier base should lead to an improved business performance due to an enhanced focus on profitable/strategic products and the related items supplied by the suppliers. Furthermore, the strategic PPM targets align better with the SM ones by maximising technically the product modularity and minimising the number of suppliers. Increased buy item commonality across the technical product portfolio can lead to a decrease in the total number of different buy items and thus enhance the purchasing power through economies of scale from a reduced number of suppliers. Every buy item within the product portfolio needs a supplier, which requires being selected, managed and developed. Additionally, these items require a nominated item owner who is connected and collaborates with the related supplier manager. The SM needs to be represented in the product portfolio analysis and decision-making process 
directly or via higher-level supply chain process representatives. The senior management should define, align and communicate the targets setting and incentives given to the PPM and SM stakeholders as well as their own roles and how they should cooperate.

\section{Conclusion}

This study analyses the interactions between PPM and SM as well as their strategic alignment. The proposed alignment was developed as the current literature only emphasises the main critical issues and related means or methods in linking a product portfolio with SM.

The study provided thorough knowledge on the subject in the analysed company, defining the challenges related to these topics as well as providing a basis for framing the strategic alignment between PPM and SM. PPM seems to be a generic challenge as it is neither clearly understood nor implemented. Therefore, strategic alignment of PPM and $\mathrm{SM}$ is also challenging in terms of governance, data sharing and target setting.

This research connects the strategic roles of PPM and SM to improve the management of the strategic product portfolio, buy items and suppliers. PPM affects the performance of SM by frequently renewing the product portfolio and thus enabling the SM to manage only the suppliers who supply the buy items related to the group of products that create the highest strategic fit, maximised value and balance for the company and its stakeholders. PPM and SM targets are fundamentally supporting each other. The presented alignment between PPM and SM links the recommended products, buy items and suppliers according to the three basic performance objectives as strategic fit, value maximisation and balance resulting in improved competitive effectiveness. The preconditions for aligning PPM and SM are also described.

The limitations of this article include only analysing a single company and their relevant practices and processes. The perspective taken in this study is purely a systemic view of PPM and SM as a system managed by company managers, excluding other potentially valid perspectives. In addition, the utilised literature is limited to those articles that could be identified during the searches. Hence, the contributions are limited to those that can be distilled based on the analysed literature and company analyses. Any potential researcher subjectivity is attempted to reduce by the analysis being conducted and confirmed by more than one person. Naturally, there is always a possibility that something has been misjudged; however, the literature is covered rather extensively, reducing the significance of individual articles. In addition, the analysed company is rather significant to justify its selection. Although there may be some limitations in the generalisability of the findings, the generalisability is attempted to be increased by carefully selecting the analysed company. Including a higher number of companies to be analysed might somewhat influence the results and the drawn conclusions. Additionally, including the perspectives of suppliers as well as quantitative analysis on the topic might provide valuable added contribution. Nevertheless, the chosen approach should provide a more nuanced, empirically rich and holistic account of the analysed phenomena. 
Appendix: Analysis template for connecting PPM and SM

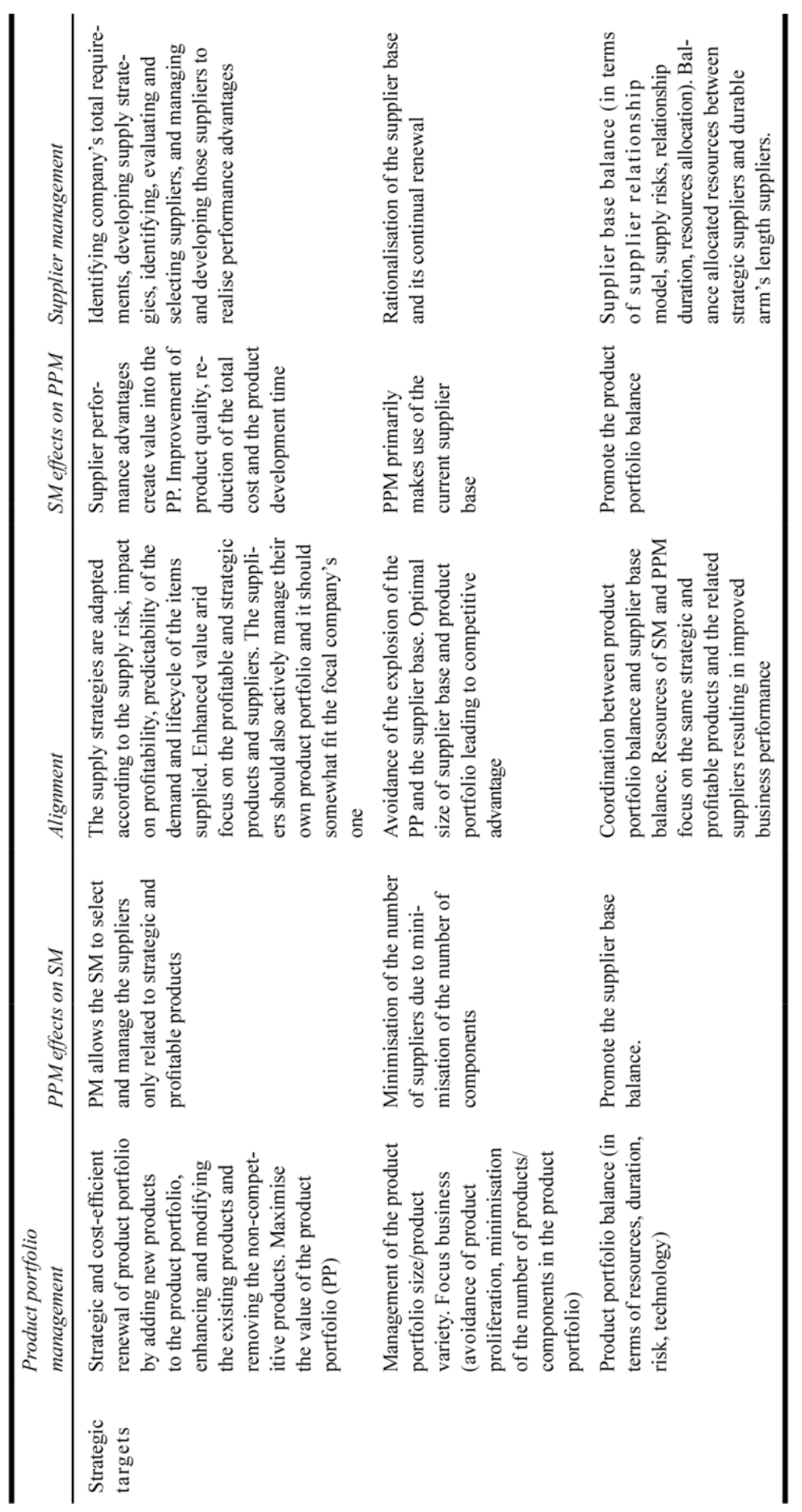


Appendix: Analysis template for connecting PPM and SM (Continued)

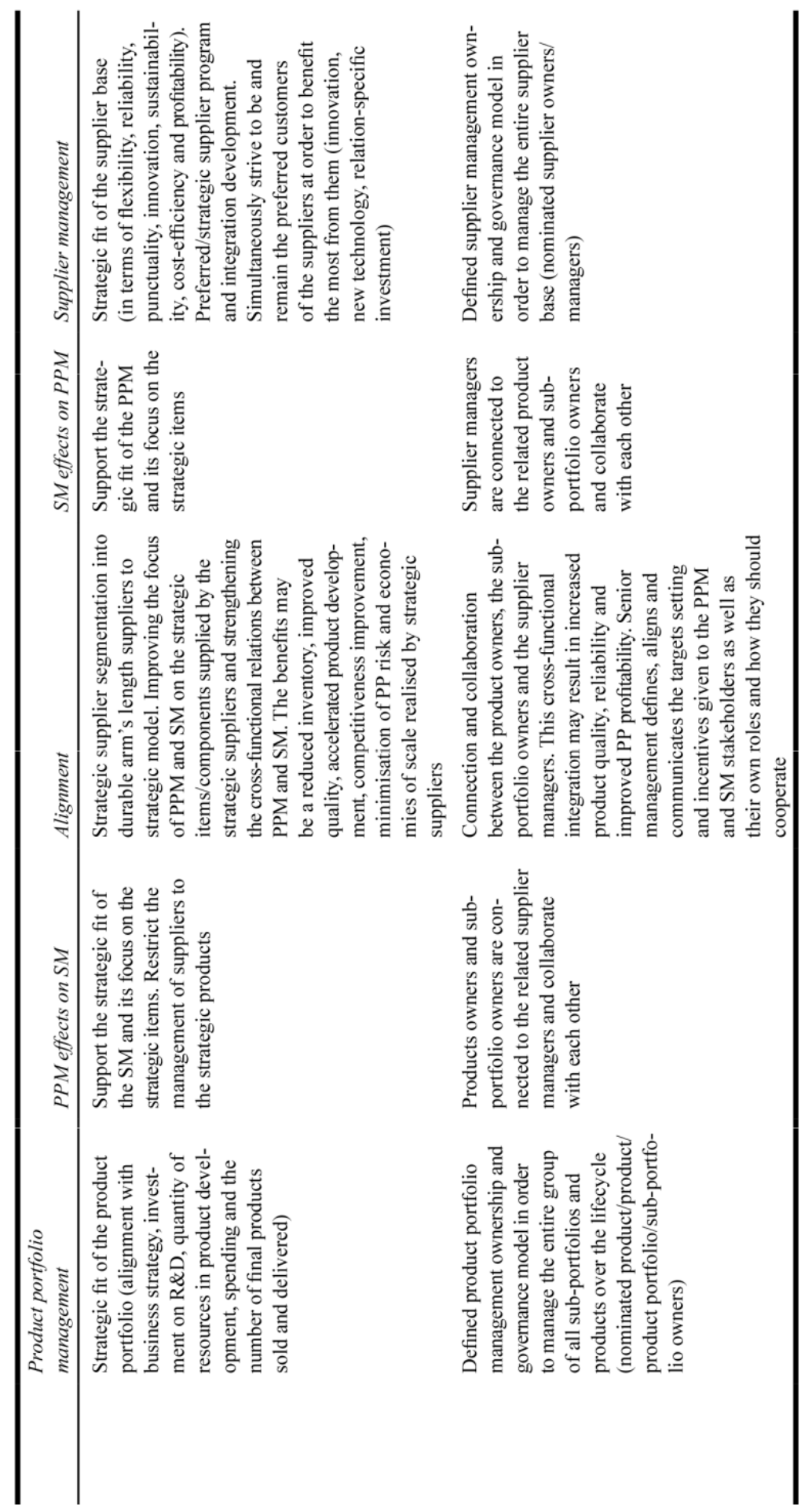


Appendix: Analysis template for connecting PPM and SM (Continued)

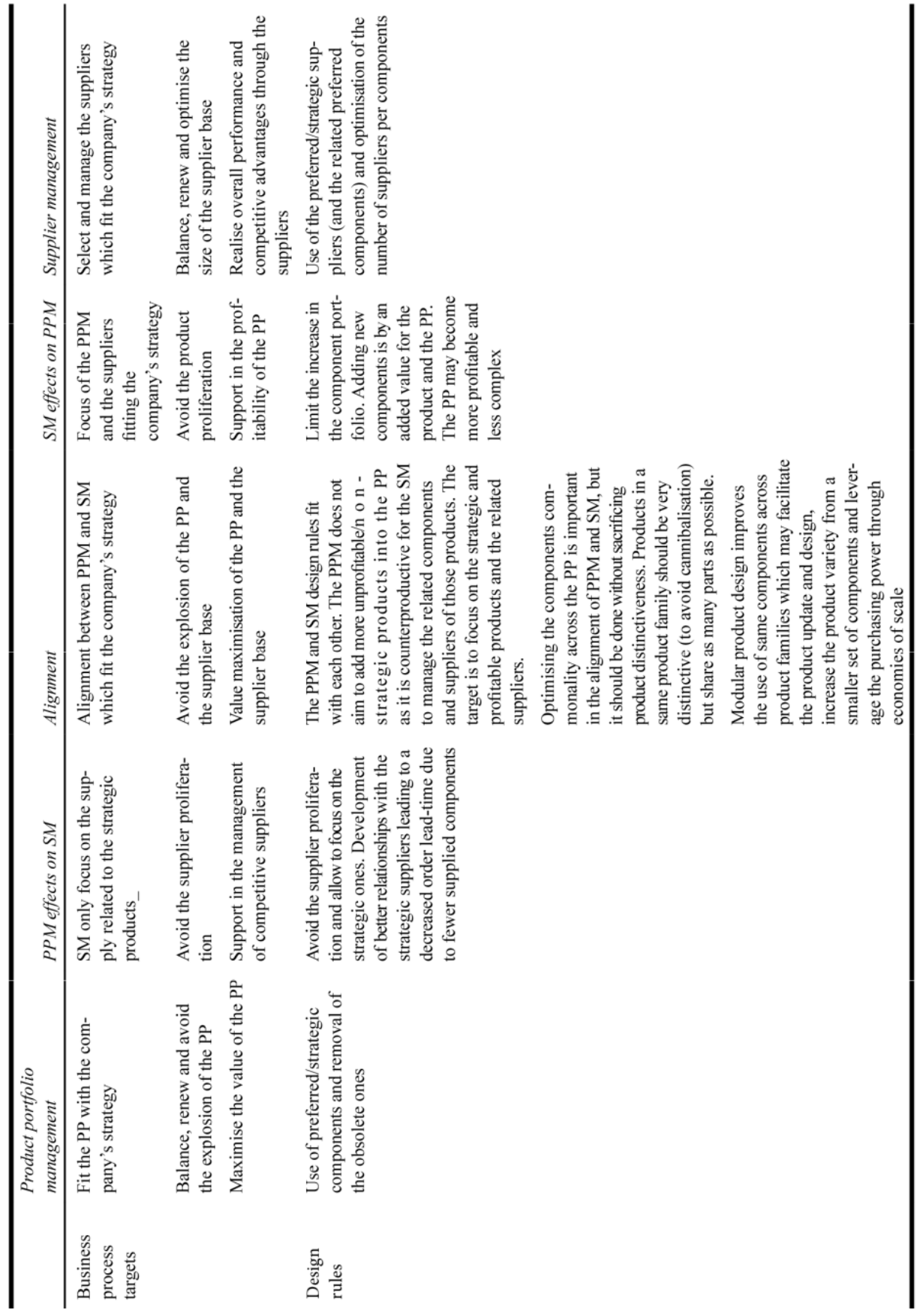


Appendix: Analysis template for connecting PPM and SM (Continued)

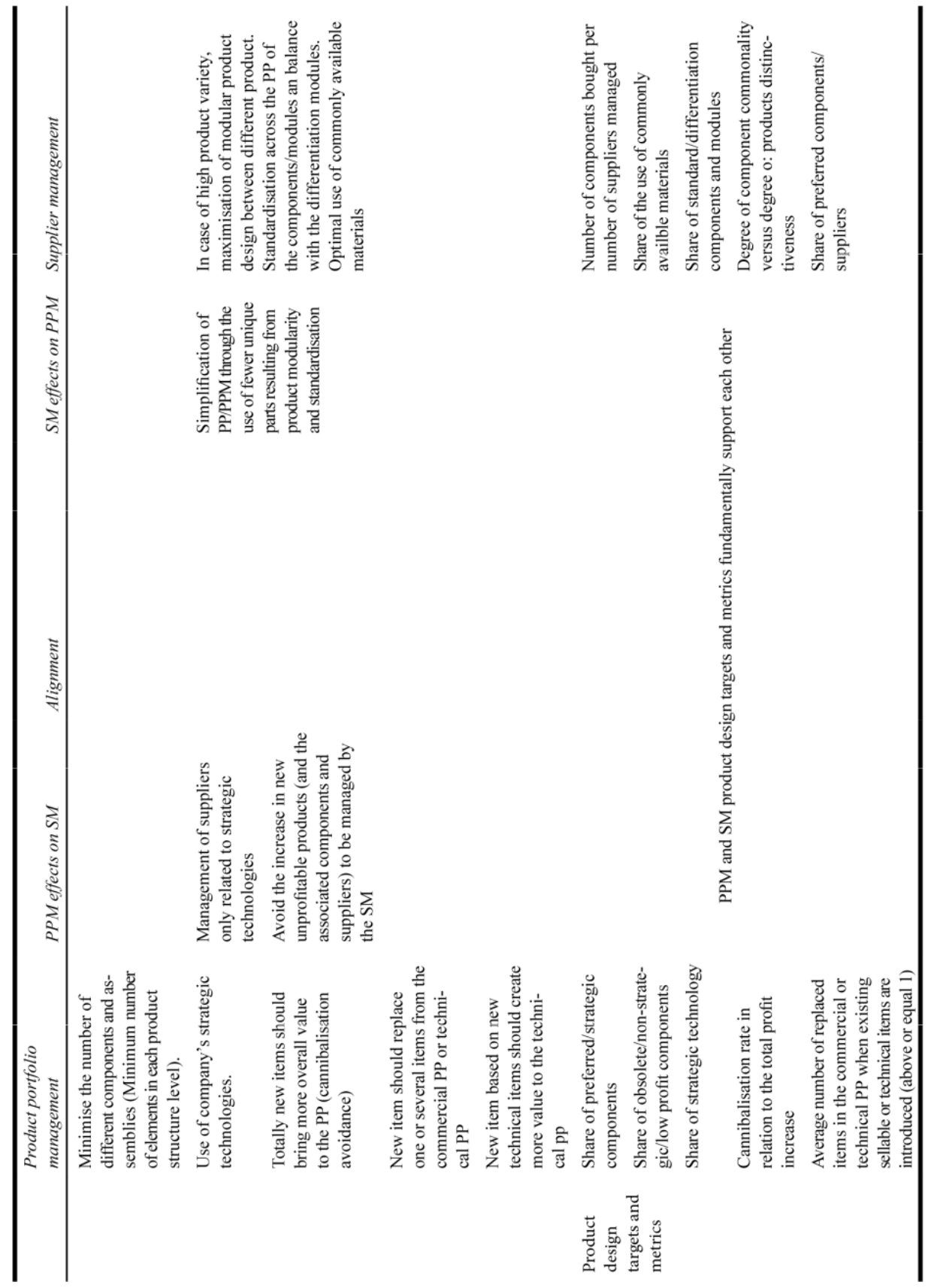




\section{References}

Abbey, J.D., Guide, V.D.R. and Souza, G.C. (2013) 'Delayed differentiation for multiple lifecycle products', Production and Operations Management, Vol. 22, No. 3, pp.588-602.

Arbnor, I. and Bjerke, B. (2008) Methodology for Creating Business Knowledge, Sage: Thousand Oaks, CA.

Bai, C. and Sarkis, J. (2013) 'A grey-based DEMATEL model for evaluating business process management critical success factors', International Journal of Production Economics, Vol. 146, No. 1, pp.281-292.

Barczak, G., Griffin, A. and Kahn, K.B. (2009) 'Perspective: trends and drivers of success in NPD practices: results of the 2003 PDMA best practices study', Journal of Product Innovation Management, Vol. 26, No. 1, pp.3-23.

Blome, C. and Schoenherr, T. (2011) 'Supply chain risk management in financial crises - A multiple case-study approach', International Journal of Production Economics, Vol. 134, No. 1, pp.43-57.

Burt, D.N. (1989) 'Managing product quality through strategic purchasing', Sloan Management Review, Vol. 30, No. 1, pp.39-47.

Cadden, T. and Downes, S.J. (2013) 'Developing a business process for product development', Business Process Management Journal, Vol. 19, No. 4, pp.715-736.

Chan, F.T.S., Kumar, N., Tiwari, M.K., Lau, H.C.W. and Choy, K.L. (2008) 'Global supplier selection: a fuzzy-AHP approach', International Journal of Production Research, Vol. 46, No. 14, pp.3825-3857.

Chen, I.J. and Paulraj, A. (2004) 'Understanding supply chain management: critical research and a theoretical framework', International Journal of Production Research, Vol. 42, No. 1, pp.131-163.

Choi, T.Y. and Hong, Y. (2002) 'Unveiling the structure of supply networks: case studies in Honda, Acura, and DaimlerChrysler', Journal of Operations Management, Vol. 20, No. 5, pp.469-493.

Choi, T.Y. and Krause, D.R. (2006) 'The supply base and its complexity: implications for transaction costs, risks, responsiveness, and innovation', Journal of Operations Management, Vol. 24, No. 5, pp.637-652.

Cooper, M.C., Lambert, D.M. and Pagh, J.D. (1997) 'Supply chain management: more than a new name for logistics', The International Journal of Logistics Management, Vol. 8, No. 1, pp.114.

Cooper, R., Edgett, S.J. and Kleinschmidt, E. (1999) 'New product portfolio management: practices and performance', Journal of Product Innovation Management, Vol. 16, No. 4, pp.333-351.

Cooper, R. (2008) 'Perspective: 'the stage- gate, idea-to-launch process - update, what's new, and NexGen systems', Journal of Product Innovation Management, Vol. 25, No. 3, pp.213-232.

Cooper, R., Edgett, S.J. and Kleinschmidt, E. (2001) 'Portfolio management for new product development: results of an industry practices study', $R$ and D Management, Vol. 31, No. 4 , pp.361-380.

Daft, R.L. (1989) Organization Theory and Design, West Publishing, New York.

David, F.R. (1989) 'How companies define their mission', Long Range Planning, Vol. 22, No. 1, pp.90-97.

Dickson, G.W. (1966) 'An analysis of vendor selection systems and decisions', Journal of Purchasing, Vol. 2, pp.5-20.

Droge, C., Vickery, S.K. and Jacobs, M.A. (2012) 'Does supply chain integration mediate the relationships between product/process strategy and service performance? An empirical study', International Journal of Production Economics, Vol. 137, No. 2, pp.250-262.

Dyer, J.H., Cho, D.S. and Chu, W. (1998) 'Strategic supplier segmentation: the next "Best Practice" in supply chain management', California Management Review, Vol. 40, No. 2, pp.57-77. 
Eisenhardt, K.M. (1989) 'Building theories from case study research', Academy of Management Review Vol. 14, pp.532-550.

Ellinger, A.E. (2000) 'Improving marketing/logistics cross- functional collaboration in the supply chain', Industrial Marketing Management, Vol. 29, No. 1, pp.85-96.

Ellram, L.M. and Carr, A. (1994) 'Strategic purchasing: a history and review of the literature', International Journal of Purchasing and Materials Management, Vol. 30, No. 1, pp.9-19.

Erixon, G. (1996) Design for modularity, In Design for X (pp.356-379), Springer, the Netherlands.

Fisher, M.L. (1997) 'What is the right supply chain for your product?', Harvard Business Review, Vol. 75, pp.105-117.

Fisher, M.L., Ramdas, K. and Ulrich, K. (1999) 'Component sharing in the management of product variety: a study of automotive braking systems', Management Science, Vol. 45, No. 3, pp.297-315.

Fixson, S.K. (2005) 'Product architecture assessment: a tool to link product, process, and supply chain design decisions', Journal of Operations Management, Vol. 23, No. 3, pp.345-369.

Foster, S.T., Wallin, C. and Ogden, J. (2011) 'Towards a better understanding of supply chain quality management practices', International Journal of Production Research, Vol. 49, No. 8, pp.2285-2300.

Gadde, L.E. and Snehota, I. (2000) 'Making the most of supplier relationships', Industrial Marketing Management, Vol. 29, No. 4, pp.305-316.

Georgiopoulos, P., Fellini, R., Sasena, M. and Papalambros, P.Y. (2002) 'Optimal design decisions in product portfolio valuation' in ASME 2002: International Design Engineering Technical Conferences and Computers and Information in Engineering Conference, American Society of Mechanical Engineers, 29 September-2 October 2002, Montreal, Canada, pp.593-602.

Germain, R. and Iyer, K.N. (2006) 'The interaction of internal and downstream integration and its association with performance', Journal of Business Logistics, Vol. 27, No. 2, pp.29-52.

Gershenson, J.K., Prasad, G.J. and Zhang, Y. (2003) 'Product modularity: definitions and benefits', Journal of Engineering Design, Vol. 14, No. 3, pp.295-313.

Gimenez, C. and Ventura, E. (2005) 'Logistics-production, logistics-marketing and external integration: their impact on performance', International Journal of Operations \& Production Management, Vol. 25, No. 1, pp.20-38.

Goffin, K., Szwejczewski, M. and New, C. (1997) 'Managing suppliers: when fewer can mean more', International Journal of Physical Distribution \& Logistics Management, Vol. 27, No. 7, pp.422-436.

Gordon, S.R. (2008) Supplier Evaluation and Performance Excellence: A Guide to Meaningful Metrics and Successful Results, J. Ross Publishing Inc, Fort Lauderdale, Florida.

Haines, S. (2009) The Product Manager's Desk Reference, McGraw-Hill, New York.

Harland, C. (1996) 'Supply chain management: relationships, chains and networks', British Journal of Management, Vol. 7, No. 1, pp.63-80.

Hartley, J.L. and Choi, T.Y. (1996) 'Supplier development: customers as a catalyst of process change', Business Horizons, Vol. 39, No. 4, pp.37-44.

He, D.W. and Kusiak, A. (1996) 'Performance analysis of modular products', International Journal of Production Research, Vol. 34, No. 1, pp.253-272.

Ho, W., Xu, X. and Dey, P.K. (2010) 'Multi-criteria decision making approaches for supplier evaluation and selection: a literature review', European Journal of Operational Research, Vol. 202, No. 1, pp.16-24.

Hoffmann, P., Schiele, H. and Krabbendam, K. (2013) 'Uncertainty, supply risk management and their impact on performance', Journal of Purchasing and Supply Management, Vol. 19, No. 3, pp.199-211.

Hoole, R. (2006) 'Drive complexity out of your supply chain', Harvard Business Review, Vol. 44, pp.1-5. 
Hsuan, J. (1999) 'Impacts of supplier-buyer relationships on modularization in new product development', European Journal of Purchasing \& Supply Management, Vol. 5, Nos. 3-4, pp.197-209.

Huang, C.C. and Kusiak, A. (1998) 'Modularity in design of products and systems', Systems, Man and Cybernetics, Part A: Systems and Humans, IEEE Transactions, Vol. 28, No.1, pp.66-77.

Jack, E.P. and Powers, T.L. (2015) 'Managing strategic supplier relationships: antecedents and outcomes', Journal of Business \& Industrial Marketing, Vol. 30, No. 2, pp.129-138.

Jacobs, M.A. (2013) 'Complexity: toward an empirical measure', Technovation, Vol. 33, No. 4, pp.111-118.

Jacobs, M.A. and Swink, M. (2011) 'Product portfolio architectural complexity and operational performance: incorporating the roles of learning and fixed assets', Journal of Operations Management, Vol. 29, Nos. 7-8, pp.677-691.

Jiao, J.R., Simpson, T.W. and Siddique, Z. (2007) 'Product family design and platform-based product development: a state-of-the-art review', Journal of Intelligent Manufacturing, Vol. 18, No. 1, pp.5-29.

Jose, A. and Tollenaere, M. (2005) 'Modular and platform methods for product family design: literature analysis', Journal of Intelligent manufacturing, Vol. 16, No. 3, pp.371-390.

Jugend, D. and da Silva, S.L. (2014) 'Product-portfolio management: a framework based on methods, organization, and strategy', Concurrent Engineering, Vol. 22, No. 1, pp.17-28.

Karlsson, C. and Sköld, M. (2007) 'Counteracting forces in multi-branded product platform development', Creativity and Innovation Management, Vol. 16, No. 2, pp.133-141.

Kester, L., Griffin, A., Hultink, E.J. and Lauche, K. (2011) 'Exploring portfolio decision-making processes', Journal of Product Innovation Management, Vol. 28, No. 5, pp.641-661.

Kester, L., Hultink, E.J. and Lauche, K. (2009) 'Portfolio decision-making genres: a case study', Journal of Engineering and Technology Management, Vol. 26, No. 4, pp.327-341.

King, D.L., Case, C.J. and Premo, K.M. (2010) 'Current mission statement emphasis: be ethical and go global', Academy of Strategic Management Journal, Vol. 9, No. 2, pp.71-87.

Kraljic, P. (1983) 'Purchasing must become supply management', Harvard Business Review, Vol. 61, No. 5, pp.109-117.

Krause, D.R. (1999) 'The antecedents of buying firms' efforts to improve suppliers', Journal of Operations Management, Vol. 17, No. 2, pp.205-224.

Krishnan, V. and Gupta, S. (2001) 'Appropriateness and impact of platform-based product development', Management Science, Vol. 47, No. 1, pp.52-68.

Lambert, D.M. and Cooper, M.C. (2000) 'Issues in supply chain management', Industrial Marketing Management, Vol. 29, No. 1, pp.65-83.

Lamming, R. (1993) Beyond Partnership: Strategies for Innovation and Lean Supply, Prentice Hall, London.

Lamming, R., Johnsen, T., Zheng, J. and Harland, C. (2000) 'An initial classification of supply networks', International Journal of Operations and Production Management, Vol. 20, No. 6, pp.675-691.

Langenberg, K.U., Seifert, R.W. and Tancrez, J.S. (2012) 'Aligning supply chain portfolios with product portfolios', International Journal of Production Economics, Vol. 135, No. 1, pp.500513.

Larson, P.D. (1994) 'Buyer-supplier co-operation, product quality and total costs', International Journal of Physical Distribution and Logistics Management, Vol. 24, No. 6, pp.4-10.

Lee, H.L. (2002) 'Aligning supply chain strategies with product uncertainties', California Management Review, Vol. 44, No. 3, pp.105-119.

Lee, H. and Wellan, D.M. (1993) 'Vendor survey plan: a selection strategy for JIT/TQM suppliers', Industrial Management and Data Systems, Vol. 93, No. 6, pp.8-13. 
Leenders, M.R., Nollet, J. and Ellram, L.M. (1994) 'Adapting purchasing to supply chain management', International Journal of Physical Distribution and Logistics Management, Vol. 24, No. 1, pp.40-42.

Lemke, F., Goffin, K., Szwejczewski, M., Pfeiffer, R. and Lohmüller, B. (2000) 'Supplier base management: experiences from the UK and Germany', The International Journal of Logistics Management, Vol. 11, No. 2, pp.45-58.

Mansoornejad, B., Chambost, V. and Stuart, P. (2010) 'Integrating product portfolio design and supply chain design for the forest biorefinery', Computers and Chemical Engineering, Vol. 34, No. 9, pp.1497-1506.

McCutcheon, D.M., Raturi, A.S. and Meredith, J.R. (1994) 'The customization-responsiveness squeeze', Sloan Management Review, Vol. 35, No. 2, pp.89-99.

McIvor, R., Humphreys, P. and Cadden, T. (2006) 'Supplier involvement in product development in the electronics industry: a case study', Journal of Engineering and Technology Management, Vol. 23, No. 4, pp.374-397.

McNally, R.C., Durmusoglu, S.S., Calantone, R.J. and Harmancioglu, N. (2009) 'Exploring new product portfolio management decisions: the role of managers' dispositional traits', Industrial Marketing Management, Vol. 38, No. 1, pp.127-143.

Miguel, P.A.C. (2008) 'Portfolio management and new product development implementation: a case study in a manufacturing firm', International Journal of Quality and Reliability Management, Vol. 25, No. 1, pp.10-23.

Mikkola, J.H. (2001) 'Portfolio management of R\&D projects: implications for innovation management', Technovation, Vol. 21, No. 7, pp.423-435.

Monczka, R.M. and Trent, R.J. (1991) 'Evolving sourcing strategies for the 1990s', International Journal of Physical Distribution and Logistics Management, Vol. 21, No. 5, pp.4-12.

Monczka, R.M., Trent, R.J. and Callahan, T.J. (1993) 'Supply base strategies to maximize supplier performance', International Journal of Physical Distribution and Logistics Management, Vol. 23, No. 4, pp.42-54.

Morssinkhof, S., Wouters, M. and Warlop, L. (2011) 'Effects of providing total cost of ownership information on attribute weights in purchasing decisions', Journal of Purchasing and Supply Management, Vol. 17, No. 2, pp.132-142.

O'Reilly III, C.A. and Tushman, M.L. (2004) 'The ambidextrous organization', Harvard Business Review, Vol. 82, No. 4, pp.74-81.

Oh, J., Yang, J. and Lee, S. (2012) 'Managing uncertainty to improve decision-making in NPD portfolio management with a fuzzy expert system', Expert Systems with Applications, Vol. 39, No. 10, pp.9868-9885.

Pashaei, S. and Olhager, J. (2015) 'Product architecture and supply chain design: a systematic review and research agenda', Supply Chain Management: An International Journal, Vol. 20, No. 1, pp.98-112.

Petroni, A. and Panciroli, B. (2002) 'Innovation as a determinant of suppliers' roles and performances: an empirical study in the food machinery industry', European Journal of Purchasing and Supply Management, Vol. 8, No. 3, pp.135-149.

Philpotts, M. (1996) 'An introduction to the concepts, benefits and terminology of product data management', Industrial Management and Data Systems, Vol. 96, No. 4, pp.11-17.

Phusavat, K., Kanchana, R. and Helo, P. (2007) 'Supplier management: past, present and anticipated future perspectives', International Journal of Management and Enterprise Development, Vol. 4, No. 5, pp.502-519.

Prajogo, D. and Olhager, J. (2012) 'Supply chain integration and performance: the effects of longterm relationships, information technology and sharing, and logistics integration', International Journal of Production Economics, Vol. 135, No. 1, pp.514-522.

Randall, T. and Ulrich, K. (2001) 'Product variety, supply chain structure, and firm performance: analysis of the U.S. bicycle industry', Management Science, Vol. 47, No. 12, pp.1588-1604. 
Robertson, D. and Ulrich, K. (1998) 'Planning for product platforms', Sloan Management Review, Vol. 39, No. 4, pp.19-31.

Saaksvuori, A. and Immonen, A. (2008) Product Lifecycle Management, Springer Science and Business Media, Berlin, p.116.

Sadeghi, A. and Zandieh, M. (2011) 'A game theory-based model for product portfolio management in a competitive market', Expert Systems with Applications, Vol. 38, No. 7, pp.7919-7923.

Salvador, F., Forza, C. and Rungtusanatham, M. (2002) 'Modularity, product variety, production volume, and component sourcing: theorizing beyond generic prescriptions', Journal of Operations Management, Vol. 20, No. 5, pp.549-575.

Sanders, N.R. and Premus, R. (2005) 'Modeling the relationship between firm IT capability, collaboration, and performance', Journal of Business Logistics, Vol. 26, No. 1, pp.1-23.

Saunders, M., Lewis, P. and Thornhill, A. (2007) Research Methods for Business Students, Financial Times/Prentice Hall, London.

Scott, C. and Westbrook, R. (1991) 'New strategic tools for supply chain management', International Journal of Physical Distribution and Logistics Management, Vol. 21, No. 1, pp.23-33.

Seifert, R.W. and Langenberg, K.U. (2011) 'Managing business dynamics with adaptive supply chain portfolios', European Journal of Operational Research, Vol. 215, No. 3, pp.551-562.

Shamsuzzoha, A.H.M., Takala, J. and Helo, P.T. (2010) 'Strategic outsourcing: status and prospects in global product development processes', International Journal of Management and Enterprise Development, Vol. 9, No. 1, pp.30-42.

Sigglekow, N. (2007) 'Theory building from cases: opportunities and challenges', Academy of Management Journal, Vol. 50, No. 1, pp.20-24.

Singh, G. and Ahuja, I.S. (2012) 'Just-in-time manufacturing: literature review and directions', International Journal of Business Continuity and Risk Management, Vol. 3, No. 1, pp.57-98.

Slack, N., Brandon-Jones, A. and Betts, A. (2012) Operations and Process Management: Principles and Practice for Strategic Impact, Pearson Education Limited, Harlow, England.

Spekman, R.E., Kamauff, J. and Spear, J. (1999) 'Towards more effective sourcing and supplier management', European Journal of Purchasing and Supply Management, Vol. 5, No. 2, pp.103-116.

Spina, G., Caniato, F., Luzzini, D. and Ronchi, S. (2013) 'Past, present and future trends of purchasing and supply management: an extensive literature review', Industrial Marketing Management, Vol. 42, No. 8, pp.1202-1212.

Stock, G.N., Greis, N.P. and Kasarda, J.D. (2000) 'Enterprise logistics and supply chain structure: the role of fit', Journal of Operations Management, Vol. 18, No. 5, pp.531-547.

Swift, C.O. (1995) 'Preferences for single sourcing and supplier selection criteria', Journal of Business Research, Vol. 32, No. 2, pp.105-111.

Talluri, S., DeCampos, H.A. and Hult, G.T.M. (2013) 'Supplier rationalization: a sourcing decision model', Decision Sciences, Vol. 44, No. 1, pp.57-86.

Thonemann, U.W. and Bradley, J.R. (2002) 'The effect of product variety on supply-chain performance', European Journal of Operational Research, Vol. 143, No. 3, pp.548-569.

Tolonen, A., Harkonen, J., Verkasalo, M. and Haapasalo, H. (2015b) 'Product portfolio management process over horizontal and vertical portfolios', International Journal of Product Lifecycle Management, Vol. 8, No. 3, pp.189-215.

Tolonen, A., Kropsu-Vehkapera, H. and Haapasalo, H. (2014a) 'Product portfolio management: current challenges and preconditions', International Journal of Performance Measurement, Vol. 4, No. 2, pp.69-90.

Tolonen, A., Shahmarichatghieh, M., Harkonen, J. and Haapasalo, H. (2015a) 'Product portfolio management - targets and key performance indicators for product portfolio renewal over life cycle', International Journal of Production Economics, Vol. 170, pp.468-477. 
Tolonen, A., Shahmarichatqhieh, M., Harkonen, J. and Haapasalo, H. (2014b) 'Product portfolio management - governance for commercial and technical portfolios over life cycle', Technology and Investment, Vol. 5, pp.173-183.

Trent, R.J. (2007) Strategic Supply Management: Creating the Next Source of Competitive Advantage, J. Ross Publishing Inc, Fort Lauderdale, Florida.

Ulrich, K., Sartorius, D., Pearson, S. and Jakiela, M. (1993) 'Including the value of time in designfor-manufacturing decision making', Management Science, Vol. 39, No. 4, pp.429-447.

Wan, X., Evers, P.T. and Dresner, M.E. (2012) 'Too much of a good thing: the impact of product variety on operations and sales performance', Journal of Operations Management, Vol. 30, No. 4, pp.316-324.

Ward, J., Zhang, B., Jain, S., Fry, C., Olavson, T., Mishal, H., Amaral, J., Beyer, D., Brecht, A., Cargille, B., Chadinha, R., Chou, K., DeNyse, G., Feng, Q., Padovani, C., Raj, S., Sunderbruch, K., Tarjan, R., Venkatraman, K., Woods, J., Zhou, J. (2010) 'HP transforms product portfolio management with operations research', Interfaces, Vol. 40, No. 1, pp.17-32.

Weerd, I., Brinkkemper, S., Nieuwenhuis, R., Versendaal, J. and Bijlsma, L. (2006) 'Towards a reference framework for software product management, requirement engineering', 14th IEEE International Requirements Engineering Conference, 11-15 September 2006, Minneapolis, USA, pp.319-322.

Williams, L.S. (2008) 'The mission statement: a corporate reporting tool with a past, present, and future', Journal of Business Communication, Vol. 45, No. 2, pp.94-119.

Xia, N. and Rajagopalan, S. (2009) 'Standard vs. Custom products: variety, lead time, and price competition', Marketing Science, Vol. 28, No. 5, pp.887-900.

Yadav, S.R., Mishra, N., Kumar, V. and Tiwari, M.K. (2011) 'A framework for designing robust supply chains considering product development issues', International Journal of Production Research, Vol. 49, No. 20, pp.6065-6088.

Yin, R.K. (2013) Case Study Research: Design and Methods, Sage Publications, London.

Zhao, X., Xue, L. and Zhang, F. (2014) 'Outsourcing competition and information sharing with asymmetrically informed suppliers', Production and Operations Management, Vol. 23, No. 10, pp.1706-1718. 